\title{
Beach Renourishment and Property Value Growth: The Case of Folly Beach, South Carolina
}

\author{
Calvin Blackwell, Susannah Sheldon, David Lansbury, and Dyanne Vaught*
}

ABstract. Numerous studies using a variety of methods suggest that beach renourishment generates benefits to both recreational users and property owners. To date, however, only Cordes, Gatlaff and Yezer (2001) have used repeat sales data, and they found no effect of renourishment on property values. We use a repeat sales index to investigate the effects of the Army Corps of Engineers' renourishment of Folly Beach, South Carolina. We find that beach renourishment has maintained property value appreciation rates when contrasted against rates in a comparable real estate market—nearby Isle of Palms, South Carolina.

Key words: Beach Renourishment, Repeat Sales, Property Value

JEL Classification Codes: R31, R32, Q51

\section{INTRODUCTION}

Beach renourishment can be both costly and controversial. As a result, policy makers need to know the specific costs and benefits of renourishing a beach. Although economists' attempts to measure the benefits of renourishment have produced varying estimates, only one published paper has failed to find positive benefits associated with beach improvements: Cordes, Gatzlaff and Yezer (2001) (hereafter, CGY). Using a similar approach to CGY and a new data set, we find that renourishment helps property owners maintain property value. We do so by comparing property sale prices on an eroded and renourished beach to property sales prices on a nearby beach that required no renourishment at all.

In particular, we look at two beachfront communities in South Carolina: Folly Beach (FB) and the Isle of Palms (IOP). Both communities share some common features, including similar geographic properties (e.g., both are barrier islands) and occupying the same niche in the Charleston, South Carolina real estate market. However, FB, due to its unique geographical location down current of the Charleston harbor, is subject to tremendous erosion from jetties constructed to maintain shipping access to the harbor. As a result, the Army Corps of Engineers has regularly renourished FB. The fact that the two communities are quite similar except for their experience with erosion and renourishment gives us a relatively clean look at the economic impact of renourishment. To examine this impact, we use a repeat sales index of property values on the two islands, and find that the rate of growth in property values is not statistically different. This result suggests that renourishment is effective at maintaining property values, and thus has some positive benefit to society.

\footnotetext{
* Blackwell is Associate Professor of Economics at the College of Charleston; Sheldon is Program Manager at South Carolina Sea Grant Consortium in Charleston, SC; Lansbury is Consultant at Metropolitan Commercial Valuations in Fairfax, VA; Vaught is a student at the College of Charleston.

Contact author: Calvin Blackwell, College of Charleston - School of Business and Economics, Department of Economics and Finance, 66 George Street, Charleston, SC 29424.E-mail: blackwellc@cofc.edu.
} 


\section{LITERATURE REVIEW}

This paper fits into the literature on valuing beach renourishment by replicating CGY, using- a similar dataset and method to examine the effects of renourishment. In an attempt to better understand why CGY found results that were counter to most of the literature, we present the following brief review of that literature. We begin by discussing two methodological issues; then we proceed to discuss particular papers that have reported positive benefits, and finally we complete the review with a detailed discussion of CGY's results.

\subsection{Methodological Issues}

The first methodological issue when attempting to measure the effects of renourishment is addressing the form of renourishment. There are at least three ways the beach can be renourished, and their potential benefits are not the same. The beach can be lengthened, deepened, or the features that protect the beach from erosion (e.g., dunes) can be improved. On FB, one of the two barrier islands examined in this paper, one can imagine all three types of renourishment taking place. That is lengthening through renourishment could occur at either the north end of the island or its south end, since erosion has occurred at both, shrinking the length of the beach and the island. Deepening of the beach could occur all along the extant beach by adding sand to the beach so that the average distance from the mean high tide mark and the first line of dunes increases. Finally, work to repair and strengthen the beach's dunes would be an example of improving the protective features of the beach.

The second methodological issue concerns the population being surveyed and/or impacted by beach renourishment. The literature has mostly examined two groups when determining the benefits of renourishment: recreational users and nearby property owners. While recreational users are assumed to gain benefits from larger, less-crowded beaches, property owners not only receive these benefits, but also gain from erosion control. Recreational users gain benefits from bigger, less-visited beaches, but such effects are likely subject to diminishing marginal returns. Property owners may have more ambiguous feelings about certain types of renourishment projects, for while they value the property protection provided by renourishment, some types of protection/renourishment may result in increased distances from the property owner's structures to the waterline. Generally, property owners prefer to be closer to the waterline, so a project that both increases protection and increases the distance to the waterline might be viewed negatively overall by property owners. In fact, such a situation has been observed recently in Florida, where a group of homeowners sued the Florida Department of Environmental Protection in an attempt to stop a beach renourishment project in the Florida panhandle (Stop the Beach Renourishment, Inc. v. Florida Dep't of Env'l Protection, 130 S. Ct. 2592 (2010)).

\subsection{Previous Work}

Early work valuing beach renourishment focused primarily on estimating benefits for recreational users. For example, McConnell (1977) used a contingent valuation survey to find that beach users had a higher willingness-to-pay for less crowded beaches. Unlike later researchers, McConnell did not ask participants explicitly about renourishment. Bell (1986) used a contingent valuation survey to find a positive value for 
renourishing the beach. In his survey, Bell asked participants how much more they would be willing to pay to preserve their beach. In addition to finding that participants were willing to pay a positive sum to preserve the beach, Bell found that beachgoers' willingness-to-pay increased as the square footage of the beach per person fell. Silberman and Klock (1988) also used a contingent valuation survey and found significant positive benefits to beach renourishment. But they did not attempt to measure the relationship between the amount of renourishment and the level of benefits. Instead, they merely showed survey participants pictures of beaches that had been renourished and beaches that had not. More recently, Lew and Larson (2007) used the travel cost method to estimate the benefits of renourishment for beachgoers near San Diego, California. They found a greater willingness-to-pay to use beaches with greater length, although this benefit was subject to diminishing returns. Lew and Larson also found beaches that suffered higher-than-average erosion were valued lower.

Landry, Keeler, and Kriesel (2003) measured the benefits of renourishment to both recreational users and property owners using two approaches: stated-preference and hedonic valuation. Employing a contingent valuation survey, they found that beachgoers prefer wider beaches and with a specific preference for how that widening is performed, preferring renourished beaches to ones that were simply widened. When they estimated a hedonic model of property values, Landry, Keeler and Kriesel found that property values did not always increase with beach renourishment. Instead, they found that while increasing the width of the beach increased property values, increasing the distance to the waterline reduced them.

Pompe and Rinehart (1995) also used a hedonic model to estimate the benefits of beach renourishment on properties near Myrtle Beach, South Carolina. Like Landry, Keeler and Kriesel (2003), Pompe and Rinehart differentiated between renourishment that increases the size of the beach and that increases the distance between the property and the beach. Also like Landry, Keeler and Kriesel, Pompe and Rinehart found that wider beaches create more valuable property, while increased distance to the beach reduces property value. In a later paper, Pompe and Rinehart (1999) essentially replicate their findings using data from Seabrook Island, South Carolina.

Using data from the state of Delaware, Parsons and Powell (2001) estimated the lost property value associated with beach erosion. Similarly, Raybould and Mules (1995) found that increased beach erosion led to lost tourism revenue, and conclude that renourishment has positive value.

\subsection{Cordes, Gatzlaff and Yezer (2001)}

To date, CGY appear to be the only researchers to use a repeat sales index to value beachfront protection. The hedonic pricing method, in which property values and property characteristics are used to measure the value of different attributes of the beach, has been used many times (see the above discussion, e.g, Landry, Keeler and Kriesel, 2003; Pompe and Rinehart, 1995; and Parsons and Powell, 2001), and typically estimates a positive value to beach protection and/or enlargement. The repeat sales method, like the hedonic pricing method, uses actual market transactions. In this method, properties that sell more than once over some sample period are aggregated into an index, and then the evolution of that index is taken as an index of overall property values. A major advantage 
of the repeat sales method over hedonic pricing is the potential elimination of omitted variable bias. Because the repeat sales method uses the exact same properties and looks at their values over time, presumably no characteristic that could influence the price are left out of the regression model. However, the repeat sales index can be biased if the features of the property change over time, e.g., if the homeowner adds square footage to the home.

In their paper, CGY create a repeat sales index for property in three Florida counties. They find that the repeat sales index does not show a statistically significant increase in response to increases in the amount of money spent by the Army Corps of Engineers (ACE) or to the existence of ACE projects. CGY propose several possible reasons for this finding. First, they point out that the amount of money spent over their study period is small and, so, may have had little effect. Second, they suggest that perhaps the regulations that often accompany ACE projects may offset the benefits of those same projects. And third, they observe that the time period studied did not include any major storm-produced erosion.

Some additional possible explanations for CGY's findings include data variability and the fact the CGY were the only researchers to use data from these three Florida counties, as well as the use of the repeat sales index itself. Perhaps something about the technique and/or the data CGY used just happened to cause their null result. More substantively, perhaps the measure used by CGY was insufficiently precise. In papers by Pompe and Rinehart and by Landry, Keeler and Kriesel, renourishment was measured in terms of both widening the beach and increasing the distance between property and the beach. CGY's measure lumped all of that information together-simply, the amount spent on renourishment projects. As outlined previously, these projects take various forms, some leading to wider beaches and other leading to a greater distance to the water. It is possible that these offsetting valuations could have caused CGY to fail to find a measurable impact.

Another issue that may help explain CGY's anomalous results is the nature of the measurement regarding the beach. Some researchers look at the value of widening the beach, while other researchers look at the value of renourishing the beach. In the first case the value of a gain is measured while in the second the value of mitigating a loss is measured. As mentioned earlier, Landry, Keeler and Kriesel (2003) found different valuations for the same renourishment project, depending upon whether it was presented to survey participants as simply widening a beach or renourishing it to a previous width. The distinction between gains and losses may be important and, hence, may help to explain CGY's results. We suspect that markets may value preservation differently from expansion. That is, CGY were looking for increased property values due to increased beach size and could not measure a benefit. It may be that if they had looked at beach protection measures, they would have found a benefit. This result is consistent with broader psychological and economic research showing that people value gains differently from preventing losses (see for example the classic work of Kahneman and Tversky (1979)). So for example, if the beach on FB has always been 40-feet deep, then property owners are willing to pay a positive sum to preserve the size of the beach at that distance. But having bought into the size of their beach, homeowners may be unwilling to pay more to its depth increased. Indeed, they may even wish to be compensated if it is deepened. 


\section{BACKGROUND}

Folly Beach (FB) and the Isle of Palms (IOP) have similar geographic properties, as shown in Figure 1, a map of the Charleston area. Both communities are on barrier islands, with similar erosion and accretion patterns. Both islands share South Carolina's typical tidal range of approximately 1.5 to 3.5 meters (Hayes, 1975). There are numerous inlets to accommodate the high volume of water from tides. The barrier island coast is ebb tidal dominant, so tidal deltas form on the seaward side of the islands, and there is an abundance of salt marshes behind the islands (Fitzgerald, 1988).

The two islands share similar histories, and play similar roles in the greater Charleston community. Both islands serve as beach destinations for locals and tourists. IOP has a slightly longer history as a tourist destination, and is perceived as somewhat more upscale than FB. The development of IOP began at the turn of the $20^{\text {th }}$ century with the opening of an amusement park on the island. FB's development was slower, but there were a substantial number of homes and a major hotel on FB by the 1930s, when George Gershwin composed the opera Porgy and Bess while staying on the island. In the 1970s,

\section{Figure 1. Satellite Image of Folly Beach and the Isle of Palms, South Carolina, with the Charleston Harbor Jetties and the Pattern of Longshore Drift Overlaid}

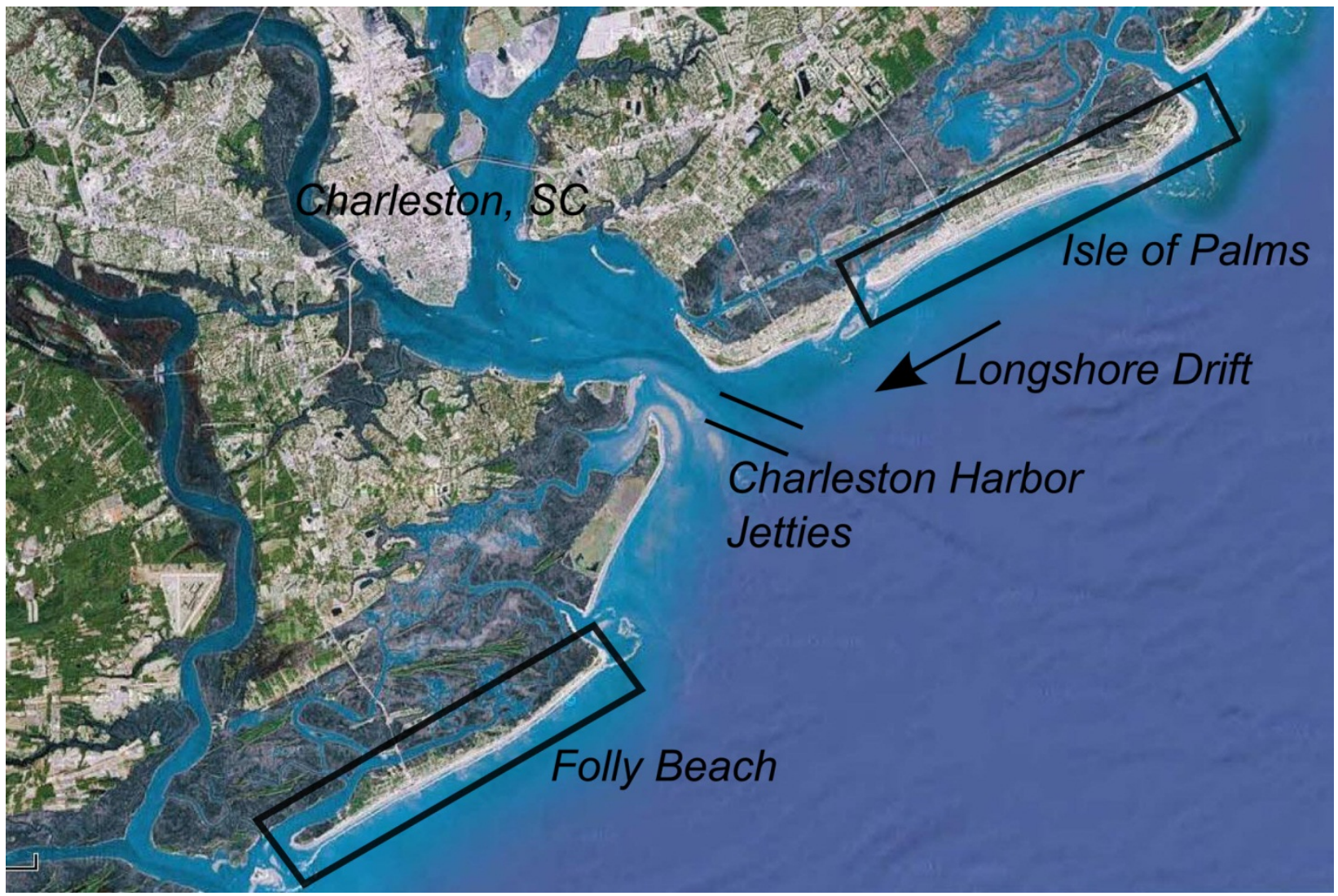

Source: Google Earth. Accessed April 11, 2007. 
Wild Dunes, ${ }^{1}$ a world class resort, opened on IOP. Although nothing as fancy as Wild Dunes exists on FB, both islands are today seen as attractive beach destinations (City of Isle of Palms, 2011; City of Folly Beach, 2011).

As shown in Figure 1, both islands are a similar distance from Charleston, the nearest large urban area. Thus, the primary economic forces faced by both communities are largely the same- - both communities provide labor and recreational opportunities to the Charleston area and both are influenced by Charleston's real estate market. Table 1 presents U.S. Census Bureau data on FB, IOP, and the greater Charleston area for the years 1990 and 2000. This data includes total population, demographic, economic and real estate market information in each community. The two island communities are of comparable size, racial makeup and household composition.

The one real difference between the two communities is median income. Households on IOP report having a significantly higher income than households on FB. We will see that these higher incomes result in higher property values, but these incomes seem to grow at approximately the same rate (FB: 6.5 percent growth/year, Isle of Palms:

Table 1. U.S. Census Data for Folly Beach and the Isle of Palms, 1990 and 2000

\begin{tabular}{l|rrr|rrr}
\hline \hline & \multicolumn{3}{|c|}{ 1990 Census } & \multicolumn{3}{c}{ 2000 Census } \\
\cline { 2 - 7 } Variable & $\begin{array}{c}\text { Folly } \\
\text { Beach }\end{array}$ & $\begin{array}{l}\text { Isle of } \\
\text { Palms }\end{array}$ & Charleston & $\begin{array}{c}\text { Folly } \\
\text { Beach }\end{array}$ & $\begin{array}{c}\text { Isle of } \\
\text { Palms }\end{array}$ & Charleston \\
\hline Population & 1,398 & 3,682 & 80,414 & 2,116 & 4,583 & 96,650 \\
\% White & 99.3 & 99.6 & 57.2 & 96.6 & 98.2 & 63.1 \\
\% Black & 0.1 & 0 & 41.6 & 0.8 & 0.3 & 34.0 \\
\% Male & 51.6 & 50.8 & 47.2 & 51.0 & 49.6 & 47.3 \\
Median Age & $40-44$ & $40-44$ & $30-34$ & 41.1 & 44.9 & 33.2 \\
Unemployment Rate & 6.9 & 4.6 & 5.4 & 2.3 & 0.8 & 4.1 \\
\% Bachelor's Degree or More & 33.2 & 42.7 & 29.5 & 50.7 & 59.7 & 37.5 \\
\% Married & 65.6 & 63.7 & 46.3 & 47.6 & 67.2 & 43.2 \\
Total Housing Units & 1,391 & 3,063 & 34,322 & 1,747 & 3,881 & 44,563 \\
\% Occupied Units & 47.9 & 48.4 & 89.6 & 60.7 & 50.0 & 91.5 \\
\% Owner Occupied & 28.5 & 38.3 & 43.1 & 35.4 & 40.4 & 46.8 \\
\% Renter Occupied & 19.3 & 10.1 & 46.5 & 25.3 & 9.6 & 44.8 \\
Mean Contract Rent (\$) & 411 & 558 & 341 & 821 & 1,169 & 614 \\
Median Household Income (\$) & 28,413 & 47,702 & 25,153 & 46,935 & 76,170 & 35,295 \\
\hline \hline
\end{tabular}

\footnotetext{
${ }^{1}$ Wild Dunes was the location for Lucas v. South Carolina Coastal Council, 505 U.S. 1003 (1992), the case in which David Lucas claimed that South Carolina’s Beachfront Management Act (1988) constituted a taking of his beachfront property.
} 
Table 2. Real Estate Market Data, 2002-2005, from Pompe (2008)

\begin{tabular}{lrrrrrr}
\hline \hline Variable & $\begin{array}{c}\text { Folly } \\
\text { Beach }\end{array}$ & \multicolumn{1}{c}{$\begin{array}{c}\text { Isle of } \\
\text { Palms }\end{array}$} & $\begin{array}{c}\text { Dewees } \\
\text { Island }\end{array}$ & $\begin{array}{c}\text { Sullivan’s } \\
\text { Island }\end{array}$ & $\begin{array}{c}\text { Kiawah } \\
\text { Island }\end{array}$ & $\begin{array}{c}\text { Seabrook } \\
\text { Island }\end{array}$ \\
\hline Avg. Price & $\$ 598,478$ & $\$ 861,769$ & $\$ 1,247,900$ & $\$ 1,100,404$ & $\$ 1,192,559$ & $\$ 606,227$ \\
Avg. Square Footage & 1,630 & 2,132 & 2,570 & 2,492 & 2,825 & 2,306 \\
Avg. Age & 30.2 & 29.7 & 9.1 & 52.5 & 15.6 & 17.3 \\
Number of Sales & 340 & 450 & 10 & 170 & 589 & 348 \\
\hline \hline
\end{tabular}

4.1 percent growth/year) with FB catching up slightly between 1990 and 2000. Although IOP is more affluent, both communities are more affluent than Charleston with both communities having higher median incomes, higher rents, and higher rates of educational attainment. Table 2, taken from Pompe (2008), provides real estate data on FB, IOP, and four other barrier island communities near Charleston. These data show that of the six communities, FB is most similar to IOP, in terms of property value, size, and age. The point of all of this comparison is that FB and IOP are very similar communities, and they occupy similar, if not identical, niches in the Charleston area real estate market. Given their similar roles, we expect that property values on the two barrier islands should grow comparably.

\subsection{Erosion and Renourishment on Folly Beach}

Although the two communities are similar in many ways, they do differ in at least one significant way: human-induced erosion. For historical, political and economic reasons, FB is subject to tremendous erosive forces. In 1898, the Army Corps of Engineers completed building two jetties to the entrance of Charleston's harbor. These jetties were built to maintain shipping access to Charleston harbor by preventing sand from collecting at the harbor's entrance. Although initially these jetties caused FB to accrete, the long-term effect of the jetties has been extreme erosion of the beach. This erosion is mainly due to primary movement of sediment along this part of the South Carolina coast, which runs from northeast to southwest. This longshore drift causes the many barrier islands (like FB and IOP) to accrete on their northeastern side and erode on their southwestern side. To help illustrate these forces, Figure 1 shows the jetties and the direction of longshore drift. When the Charleston Harbor jetties were built, they disrupted the longshore drift for FB, preventing sediment from accreting on its northeastern side. With the natural renourishment process disrupted, FB began to erode. Figure 1 shows the basic layout of the area under study. Notice that FB is south of IOP and the Charleston Harbor jetties (Owens and Rogers, 2007).

In order to counteract the effects of the Charleston Harbor jetties, the Army Corps of Engineers (ACE) began a program of beach renourishment in 1989. Before then, a few locally funded renourishment projects had been undertaken on FB. The ACE program has been quite effective. Levine et al. (2009) estimate that current rates of erosion on FB range from 0.3 to 1.8 meters per year, down from 2.7 to 4.5 meters rate per year averaged between 1854 and 1977. The ACE renourished the beach in 1993, 1998, 1999, 2003, 2005, and 2007 (Owens and Rogers, 2007). Since 1986, IOP has had no renourishment projects. 


\section{HYPOTHESIS}

We attempt to ascertain the effect of renourishment upon the property values of FB. To do so, we examine data from a similar real estate market, IOP, and observe how changes in real estate values differ between the two markets. We assume that because of their similarities, all relevant factors affecting real estate values on the two islands are the same with one exception: renourishment. Any differences in changes in real estate values in the two markets can then be attributed to the effect of renourishment. If that program is effective, then there ought to be no difference in property values between the two real estate markets. In particular, we look at rates of appreciation over a 20 -year period with a null hypothesis that the rate of appreciation on FB is the same as that on IOP.

\section{DATA AND METHODOLOGY}

We examine property values on FB and IOP. In particular, we focus on property with values most likely to be affected by beach renourishment-beachfront property and those properties immediately behind them. FB and IOP share the same basic real estate development pattern. Homes are located on lots immediately adjacent to the beach and these lots run parallel to the beach. Opposite the beachside of the home is a street, and across the street is another line of homes. Our data set consists of all the properties on the beachfront and that first row: moreover, it is also limited to those properties that were bought and sold at least two times between 1986 and 2005. We use sales data from the Charleston County South Carolina Assessors’ Office deflated to 1984 dollars. $^{2}$

We look at ACE renourishment as an opportunity to apply a differences-indifferences approach. Two similar entities, the real estate markets on FB and IOP, received differing policy interventions. IOP had no human-induced erosion and had no renourishment projects. FB suffered from human-caused erosion and had its beach renourished several times. The rates of appreciation from 1986 on them can be compared. Because of the initial similarities between the two markets, we argue that any difference in the two real estate markets post-intervention is the result of the policy treatment.

We use the repeat sales method to examine the difference in property values on FB and IOP over the time period from 1986 to 2005. This method creates an index of price changes for properties that sell more than once during a particular time interval. We use a method originally proposed by Bailey, Muth and Nourse (1963) that assumes that housing quality stays the same between sales dates so that the change in the sales price between the sales dates is purely a function of time (changes in tastes among market participants).

A major advantage of this technique is that it avoids the omitted variable bias that can occur in typical hedonic pricing models for real estate. Still, the repeat sales method itself has at least two potential weaknesses. First, bias is inherent in the results if the qualities of properties change through renovation, addition, or neglect. Second, properties

\footnotetext{
${ }^{2}$ We would have eliminated any suspicious sales, for example, transactions for $\$ 100$ or less, from the dataset. However, the smallest sale was for $\$ 30,000$, so there was no need to remove any observations.
} 
that are picked up by this method (those that sell most frequently) may not be representative of the underlying population of property values.

Following the model presented in CGY, let $P_{i t}$ be the market price of property $i$ at time $t$. If a property is initially purchased at time $T 1$ and then resold at time $T 2$, then:

$$
P_{i T 2}=P_{i T 1}\left(1+r_{1}\right)^{D i 1}\left(1+r_{2}\right)^{D i 2}\left(1+r_{3}\right)^{D i 3} \ldots\left(1+r_{n}\right)^{D i n}
$$

where $r_{t}=$ an index of cumulative appreciation through period $t$ and $D_{t}=-1$ if $t=T 1,1$ if $t=T 2$, and 0 otherwise. Dividing Equation (1) by $P_{i T 1}$ and taking the natural log results in Equation (2):

$$
\ln \left(P_{i T 2} / P_{i T 1}\right)=D_{i 2} L N\left(1+r_{1}\right)+D_{i 2} L N\left(1+r_{2}\right)+\ldots+D_{i n} \ln \left(1+r_{n}\right)
$$

If we add $\varepsilon_{i}$ as an i.i.d. random error term to Equation (2) we find the econometric model:

$$
\ln \left(P_{i T 2} / P_{i T 1}\right)=\beta_{i} D_{i 1}+\beta_{2} D_{i 2}+\beta_{3} D_{i 3}+\ldots \beta_{n} D_{i n}+\varepsilon_{i}
$$

To investigate the potential impact of renourishment on FB, we create a series of dummy variables and incorporate them into Equation (3):

$$
\ln \left(P_{i T 2} / P_{i T 1}\right)=\beta_{i} D_{i 1}+\beta_{2} D_{i 2}+\beta_{3} D_{i 3}+\ldots+\beta_{n} D_{i n}+\left(\varphi_{i} D_{i 1}+\varphi_{2} D_{i 2}+\varphi_{3} D_{i 3}+\ldots \varphi_{n} D_{i n}\right) F_{i}+\varepsilon_{i}
$$

where $F_{i}$ is a dummy variable that takes on the value 1 if the property is located on FB and 0 otherwise.

Figure 2. Average Property Prices by Year for Folly Beach and the Isle of Palms, 1986-2005

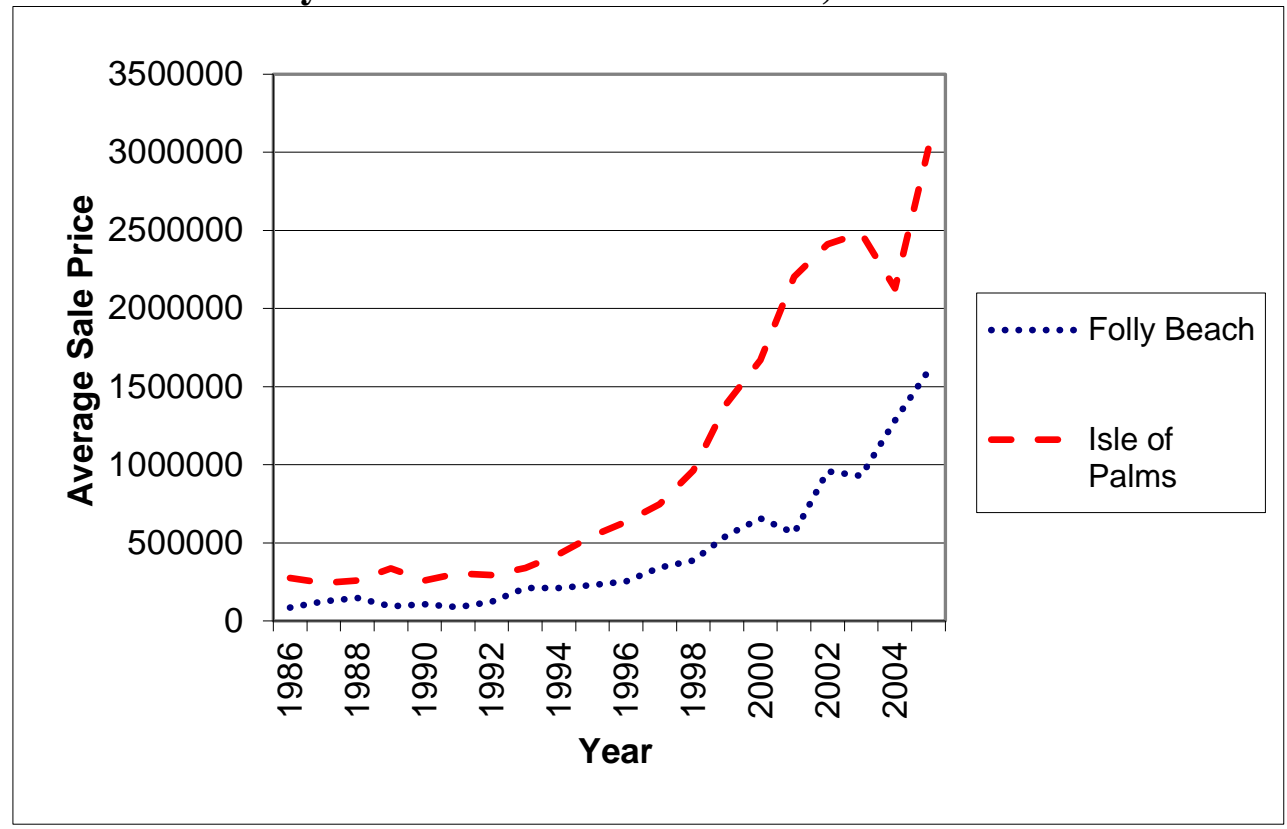

(C) Southern Regional Science Association 2012. 


\section{RESULTS}

Figure 2 shows average property prices from 1986 to 2005. We see that property values are generally higher on IOP but that property values in both municipalities grow steadily over the study period. Only one major difference in growth rates is evident in this graph-the dramatic downturn in property prices on IOP in 2004. This drop is likely due to the busy hurricane season in 2004 when Hurricane Gaston hit IOP head on. Note however that property values rather quickly rebound to their long-run pattern in the next year. This pattern of a temporary dip in prices is consistent with previous work by Ewing, Kruse and Wang (2007), who found the same pattern (a temporary dip followed by no long term effects) between wind damage and real estate prices in six metropolitan areas. Figure 2, although informative, is hardly conclusive, and so we turn to regression analysis.

Table 3 gives the definitions for the variables used to estimate Equation (4). Table 4 presents the results of estimating Equation (4) with and without the FB dummy variables. In addition to the year dummy variables, we include two control variables: the natural log of the first price the property sold for and the distance between the property and the island's main access road. The initial price is used to control for the fact that more expensive homes tend to appreciate more slowly than less expensive homes (this fact is illustrated by the negative, significant coefficient in the regression). The distance variable is used to control for different amenity effects. In theory, it makes sense to control for variables like the distance to the nearest marina, distance to the closest grocery store, and distance to the mainland: But all of these variables are (almost) perfectly collinear because of the geography of the islands. Each of the barrier islands has primary access

Table 3. Study Variable Definitions.

\begin{tabular}{ll}
\hline \hline Variable Name & Definition \\
\hline LOGPRATIO & $=$ the natural logarithm of the ratio of the price the property sold \\
& for the second time to the price the property sold for initially, \\
& using prices deflated to 1984 dollars \\
& $=$ the natural logarithm of the price (deflated to 1984 dollars) the \\
& property sold for the first time the property appears in the data set \\
& $=$ the distance in miles the property is located from the central \\
& access point to the island \\
& $=-1$ if the property was first sold in year $X X$ \\
& $=0$ if the property was not sold in year $X X$ \\
& $=1$ if the property was sold for a second time in year $X X$ \\
& $=-1$ if the property is on Folly Beach and was first sold in year \\
& $X X$ \\
& $=0$ if the property was not sold in year $X X$ or is located on IOP \\
& $=1$ if the property is on Folly Beach and was sold for a second \\
\hline \hline
\end{tabular}


time in year $X X$

Table 4. Regression Results (Dependent Variable = LOGPRATIO)

\begin{tabular}{|c|c|c|c|c|}
\hline Variable & $\begin{array}{r}\text { Model (i) Estimated } \\
\text { Coefficient }\end{array}$ & $\begin{array}{r}\text { Standard } \\
\text { Error }\end{array}$ & $\begin{array}{r}\text { Model (ii) Estimated } \\
\text { Coefficient }\end{array}$ & $\begin{array}{r}\text { Standard } \\
\text { Error } \\
\end{array}$ \\
\hline Intercept & $3.214 * * *$ & .519 & $3.615^{* * *}$ & .570 \\
\hline LNPRICEONE & $-0.241^{* * *}$ & .041 & $-0.049 * * *$ & .036 \\
\hline DISTANCE & -0.070 & .036 & -0.277 & .046 \\
\hline YR87 & -0.116 & .149 & -0.342 & .435 \\
\hline YR88 & 0.002 & .178 & -0.281 & .457 \\
\hline YR89 & -0.083 & 166 & -0.146 & .445 \\
\hline YR90 & -0.216 & .135 & -0.450 & .440 \\
\hline YR91 & -0.174 & .147 & -0.378 & .437 \\
\hline YR92 & -0.163 & .135 & -0.301 & .431 \\
\hline YR93 & 0.070 & .161 & -0.135 & .442 \\
\hline YR94 & 0.284 & .148 & 0.035 & .444 \\
\hline YR95 & 0.145 & .148 & -0.007 & .436 \\
\hline YR96 & 0.264 & .153 & 0.036 & .432 \\
\hline YR97 & $0.448 * *$ & .165 & 0.353 & .433 \\
\hline YR98 & $0.619 * * *$ & .164 & 0.627 & .453 \\
\hline YR99 & $0.825 * * *$ & .158 & $0.830 *$ & .410 \\
\hline YR00 & $1.027 * * *$ & .171 & $1.115 *$ & .439 \\
\hline YR01 & $0.931 * * *$ & .184 & $1.320^{* *}$ & .461 \\
\hline YR02 & $1.296 * * *$ & .176 & $1.571^{* * *}$ & .456 \\
\hline YR03 & $1.243^{* * *}$ & .176 & $1.223^{* *}$ & .450 \\
\hline YR04 & $1.454 * * *$ & .179 & $1.156^{* *}$ & .450 \\
\hline YR05 & $1.757 * * *$ & .189 & $1.595^{* * *}$ & .458 \\
\hline FYR87 & & & 0.400 & .478 \\
\hline FYR88 & & & 0.439 & .510 \\
\hline FYR89 & & & 0.023 & .493 \\
\hline FYR90 & & & 0.281 & .463 \\
\hline FYR91 & & & 0.297 & .473 \\
\hline FYR92 & & & 0.114 & .456 \\
\hline FYR93 & & & 0.243 & .476 \\
\hline FYR94 & & & 0.252 & .470 \\
\hline FYR95 & & & 0.193 & .462 \\
\hline FYR96 & & & 0.244 & .462 \\
\hline FYR97 & & & 0.087 & .473 \\
\hline FYR98 & & & -0.113 & .483 \\
\hline FYR99 & & & -0.159 & .441 \\
\hline FYROO & & & -0.295 & .475 \\
\hline FYR01 & & & -0.609 & .496 \\
\hline FYR02 & & & -0.528 & .490 \\
\hline FYR03 & & & -0.119 & .488 \\
\hline FYR04 & & & 0.378 & .488 \\
\hline FYR05 & & & 0.200 & .503 \\
\hline & \multicolumn{2}{|c|}{.600} & \multicolumn{2}{|c|}{.664} \\
\hline Adjusted $R^{2}$ & \multicolumn{2}{|c|}{.562} & \multicolumn{2}{|c|}{.597} \\
\hline$F$-Statistic & \multicolumn{2}{|c|}{$15.779 * * *$} & \multicolumn{2}{|c|}{$9.972 * * *$} \\
\hline Degrees of Freedom & \multicolumn{2}{|l|}{221} & \multicolumn{2}{|c|}{202} \\
\hline
\end{tabular}

(C) Southern Regional Science Association 2012. 
from a single main road that strikes the island near its geographic center. Each also has marinas, groceries and other commercial establishments that are located immediately off of this main road; this means that distance to grocery and distance to marina are practically the same. Beyond the main road in each community, property is almost exclusively residential. We cannot use distance to the beach because, by construction, all of the homes in our sample are the same distance to the beach (they are all beachfront or at most 50 yards from it). The distance variable is not significant in either regression, but we include it to prevent any omitted variable bias.

Returning to the main analysis, we see that the estimated parameters for years close in time to 1986 are not statistically significant, but later years are. This result shows that property values were generally rising over time, but that we do not have enough statistical power to capture the initial differences in property values. As these values grow larger over time, they become statistically significant. If the null hypothesis is true, that is, that renourishment has been effective in maintaining property values on $\mathrm{FB}$, then the estimated values of $\varphi$ from Equation (4) should be zero.

Note that none of the individual estimated coefficients for any particular $\varphi_{i}$ are significantly different from zero. A further $F$-test of the joint hypothesis: $\varphi_{i}=0$ is rejected $(F=2.025, p$-value $=0.01)$; however it is unclear if this rejection occurs because $\mathrm{FB}$ has higher or lower rates of appreciation (note that most of the estimated $\varphi_{i}$ are positive.) We conclude that the rates of growth of property prices on FB and IOP do not differ between 1986 and 2005.

\section{CONCLUSION}

Our study, like all empirical work, suffers from a number of limitations. Perhaps the most critical of these limitations is the assumption, necessary to apply the differencesin-differences approach, that observations come from entities that are identical in all dimensions except for the treatment effect. In practice, this assumption is never matched by reality; and we freely admit that there are some significant differences between IOP and FB. The primary difference is one of relative affluence; although both communities are wealthier than the rest of the Charleston area, IOP is more affluent than FB.

Despite the aforementioned limitations, we conclude that renourishment can help maintain property values. We have shown that the repeat-sales approach can measure positive benefits for renourishment. The inability of CGY to measure positive benefits from renourishment seems to be an anomaly. Future research should focus on refining the repeat-sales approach so that it can measure the size of the benefit more precisely so policy makers can use it in cost-benefit analyses of current and future renourishment projects. 


\section{REFERENCES}

Bailey, Martin J., Richard F. Muth and Hugh O. Nourse. (1963) “A Regression Method for Real Estate Price Index Construction,” Journal of the American Statistical Association, 58, 933-942.

Bell, Frederick W. (1986) "Economic Policy Issues Associated with Beach Renourishment,” Review of Policy Research, 6, 374-381.

City of Isle of Palms. (2010) Island History. Available from World Wide Web: http://www.iop.net/AboutUs/IslandHistory.aspx.

City of Folly Beach. (2010) History Timeline. Available from World Wide Web: http://www.follybeachsouthcarolina.org/index.aspx?NID=70.

Code of Laws of South Carolina. (1988) Beachfront Management Act. (SC ST SEC), title 48, part 39, section 10.

Cordes, Joseph J, Dean H. Gatzlaff, and Anthony M. Yezer. (2001) “To the Water's Edge, and Beyond: Effects of Shore Protection Projects on Beach Development,” Journal of Real Estate Finance and Economics, 22, 287-302.

County of Charleston, South Carolina. (2012) "Property Information System” Available from World Wide Web: http://ccgisweb.charlestoncounty.org/website/Charleston/default.htm.

Ewing, Bradley T., Jamie B. Kruse, and Yongsheng Wang. (2007) “Local Housing Price Index Analysis in Wind-Disaster-Prone Areas,” Natural Hazards, 40, 463-483.

Fitzgerald, Duncan M. (1988) "Shoreline Erosional-Depositional Processes Associated with Tidal Inlets,” Lecture Notes in Estuarine Studies, 29, 186-225.

Hayes, Miles O. (1975) “Morphology of Sand Accumulations in Estuaries,” Estuarine Research, 2, 3-22.

Kahneman, Daniel and Amos Tversky. (1979) "Prospect Theory: An Analysis of Decision under Risk,” Econometrica, 47, 263-291.

Landry, Craig E, Andrew G. Keeler, and Warren Kriesel. (2003) “An Economic Evaluation of Beach Erosion Management Alternatives," Marine Resources Economics, 18, 105-127.

Levine, Norman, Charles Kaufman, Michael Katuna, Scott Harris, and Mitchell Colgan. (2009) “Folly Beach, South Carolina: An Endangered Barrier Island,” In Joseph T. Kelley, Orrin H. Pilkey and J.A.G. Cooper (eds), America's Most Vulnerable Coastal Communities: Geological Society of America Special Paper 460, pp. 91110.

Lew, Daniel K. and Douglas M. Larson. 2007. Valuing Recreation and Amenities at San Diego County Beaches. Coastal Management, 33, 71-86.

McConnell, Kenneth E. (1977) "Congestion and Willingness to Pay: A Study of Beach Use,” Land Economics, 53, 185-195. 
National Oceanographic and Atmospheric Administration. (2004) "Tropical Storm Gaston Post-Tropical Storm Report,” Available from World Wide Web: http://www.erh.noaa.gov/chs/text/PSHCHS_09032004.txt.

Office of Ocean and Coastal Resource Management (DHEC-OCRM). (2000) “Understanding Our Coastal Environment,” South Carolina Department of Health and Environmental Control, http://www.scdhec.net/eqc/ocrm/pubs/uoce.pdf.

Owens, Kim and Elizabeth Rogers. (2007) “Explore Folly Island,” Available from World Wide Web: http://www.cofc.edu/CGOInquiry/

Parsons, George R. and Michael Powell. (2001) "Measuring the Cost of Beach Retreat," Coastal Management, 29, 91-103.

Pompe, Jeffrey J. (2008) "The Effect of a Gated Community on Property and Beach Amenity Valuation,” Land Economics, 84, 423-433.

Pompe, Jeffrey J. and James R. Rinehart. (1999) "Establishing Fees for Beach Protection: Paying for a Public Good,” Coastal Management, 27, 57-67.

. (1995) “The Value of Beach Nourishment to Property Owners: Storm Damage Reduction Benefits,” Review of Regional Studies, 25, 271-285.

Raybould, Mike and Trevor Mules. (1999) “A Cost-Benefit Study of Protection of the Northern Beaches of Australia's Gold Coast,” Tourism Economics, 5, 121-139.

Silberman, Jonathan and Mark Klock. (1988) "The Recreational Benefits of Beach Renourishment,” Ocean \& Shoreline Management, 11, 73-90.

United States Census Bureau. (2012) “1990 Census,” Available on the World Wide Web: http://www.census.gov/main/www/cen1990.html.

United States Census Bureau. (2012) “2000 Census,” Available on the World Wide Web: http://www.census.gov/main/www/cen2000.html.

(C) Southern Regional Science Association 2012. 